\title{
PENGEMBANGAN PERANGKAT PEMBELAJARAN IPA INTEGRASI COOPERATIVE SCRIPT DAN KETERAMPILAN PROSES SAINS DI KELAS IV-A SDN 049 TARAKAN
}

\author{
Sisca Ayu Azhari ${ }^{1}$, Muhsinah Annisa ${ }^{2}$ Kartini $^{3}$ \\ Universitas Borneo Tarakan ${ }^{1,2,3}$ \\ siscaayuazhari@gmail.com¹, echa.ok@gmail.com²
}

\begin{abstract}
ABSTRAK
Tujuan penelitian ini adalah untuk menghasilkan perangkat pembelajaran IPA integrasi cooperative script dan keterampilan proses sains yang layak ditinjau dari uji validasi isi, konstruk, dan bahasa serta respon siswa setelah mengikuti kegiatan pembelajaran menggunakan perangkat pembelajaran IPA integrasi cooperative script dan keterampilan proses sains di kelas IV-A SDN 049 Tarakan. . Penelitian ini menggunakan desain penelitian pengembangan model 4-D-dibatasi sampai 3 tahap (3D): Pendefinisian (define), perancangan (design), pengembangan (development). Perangkat pembelajaran yang dikembangkan berupa silabus, Rencana Pelaksanaan Pembelajaran (RPP), Buku Ajar Siswa (BAS), dan Lembar Kerja Siswa (LKS). Teknik pengumpulan data yang digunakan adalah wawancara, observasi, tes, kuesioner atau angket, dan dokumentasi. Hasil penelitian menunjukkan bahwa pengembangan perangkat pembelajaran IPA integrasi cooperative script dan keterampilan proses sains di kelas IV-A SDN 049 Tarakan sangat layak ditinjau dari hasil uji validasi isi, konstruk, dan bahasa adalah 1) Silabus dan Rencana Pelaksanaan Pembelajaran (RPP) memperoleh rata-rata 4,33 (sangat baik), 2) Buku Ajar Siswa (BAS) memperoleh rata-rata 4,27 (sangat baik), 3) Lembar Kerja Siswa (LKS) memperoleh rata-rata 4,34 (sangat baik). Berdasarkan hasil uji validasi isi, konstruk, dan bahasa secara keseluruhan menunjukkan bahwa perangkat pembelajaran memperoleh skor rata-rata sebesar 4,31 dengan kriteria sangat baik sedangkan respon siswa memperoleh kriteria sangat baik.
\end{abstract}

Kata Kunci: Perangkat pembelajaran IPA, Cooperative script, Keterampilan proses sains

\begin{abstract}
The aimed of this study is to produce science learning devices cooperative script integration and science process skills that are feasible in terms of validation of content, constructs, and language tests and student responses after participating in learning activities using science learning tools cooperative script integration and science process skills in class IV-A 049 Tarakan Elementary School. . This study used a research design development of 4-D models limited to 3 stages $(3 D)$ : Define (design), design (development). Learning tools developed in the form of syllabus, Learning Implementation Plan (RPP), Student Textbook (BAS), and Student Worksheets (LKS). Data collection techniques used were interviews, observations, tests, questionnaires or questionnaires, and documentation. The results showed that the development of science learning devices the integration of cooperative script and science process skills in class IV-A SDN 049 Tarakan was very feasible in terms of the results of validation of content, constructs, and language tests. 1) Syllabus and Learning Implementation Plan (RPP) obtained an average average 4.33 (very good), 2) Student Textbook (BAS) obtained an average of 4.27 (very good), 3) Student Worksheet (LKS) obtained an average of 4.34 (very good). Based on the results of the validation of content, constructs, and language as a whole, it shows that learning devices obtain an average score of 4.31 with very good criteria while the responses of students obtain very good criteria.
\end{abstract}

Keywords: Science learning devices, Cooperative scripts, Science process skills 


\section{PENDAHULUAN}

Pendidikan merupakan suatu usaha yang menjadi tombak untuk meningkatkan kualitas hidup manusia di suatu negara. Mustofa dan Asf (2013: 7) menjelaskan bahwa pendidikan adalah usaha sadar yang sengaja dirancang untuk mencapai tujuan yang telah ditentukan. Peran pendidikan sangat penting untuk menciptakan generasi yang cerdas, transparan, dan demokratis. Oleh karena itu, segala inovasi harus terus dilakukan untuk meningkatkan kualitas suatu bangsa melalui proses pendidikan.

Inti proses pendidikan tidak terlepas dari proses pembelajaran, dimana pembelajaran sebagai suatu proses harus dikembangkan oleh guru sehingga pelaksanaannya dapat membuat siswa mencapai tujuan pembelajaran yang telah ditetapkan. Dalam melaksanakan proses pembelajaran tersebut, guru berperan mengambil keputusan secara rasional, sadar, dan terencana mengenai tujuan pembelajaran dan pengalaman belajar yang akan diberikan kepada siswa serta menentukan berbagai sumber belajar dan instrumen evaluasi pembelajaran yang akan digunakan untuk mencapai tujuan dan pengalaman tersebut. Hal tersebut perlu didukung dengan perencanaan pembelajaran yaitu dengan mengembangkan perangkat pembelajaran dengan model pembelajaran atau pendekatan tertentu yang akan digunakan dalam pembelajaran dan mampu membantu guru maupun siswa menciptakan pendidikan yang berkualitas dalam kegiatan pembelajaran khususnya dalam pembelajaran IPA di Sekolah Dasar.

Pembelajaran IPA merupakan salah satu upaya agar siswa memahami konsepkonsep IPA dan dapat memiliki keterampilan proses untuk menjelaskan gejala-gejala alam dan memecahkan masalah dalam kehidupan sehari-hari, mencintai alam sekitar, serta menyadari kebesaran dan keagungan Tuhan. Badan Standar Nasional Pendidikan dalam Susanto (2013: 171-172) menjelaskan bahwa tujuan pembelajaran IPA di
Sekolah Dasar agar siswa memiliki kemampuan sebagai berikut: 1) meyakini keagungan Tuhan Yang Maha Esa berdasarkan rupa, wujud, dan ketetapan alam ciptaan-Nya; 2) mengembangkan wawasan siswa mengenai konsep-konsep IPA yang bermanfaat dan digunakan dalam kehidupan sehari-hari; 3) mengembangkan rasa keingintahuannya, perbuatan yang positif dan kesadaran tentang adanya hubungan timbal balik antara IPA, teknologi, masyarakat dan lingkungan; 4) mendapatkan bekal pengetahuan, konsep, dan keterampilan IPA sebagai dasar untuk melanjutkan pendidikan yang lebih tinggi; 5) meningkatkan kesadaran siswa untuk turut serta dalam merawat, melindungi, dan mempertahankan kelestarian lingkungan alam sekitar; 6) meningkatkan kesadaran siswa untuk memandang penting alam dan segala ketetapannya sebagai salah satu ciptaan Tuhan; 7) mengembangkan keterampilan proses untuk menelaah alam sekitar, melakukan pemecahan masalah, dan mengambil keputusan.

Salah satu tujuan pembelajaran IPA di Sekolah Dasar adalah mengembangkan keterampilan proses pada diri siswa, dengan demikian siswa mampu melakukan penyelidikan ilmiah, memecahkan suatu permasalahan, dan membuat keputusan atau menarik kesimpulan. Heuvelen dalam Sulistyorini, dkk (2016: 1168) menyatakan bahwa permasalahan umum yang terjadi dalam pembelajaran sains atau IPA adalah penyajian pengetahuan yang terlalu banyak membahas fakta dan hukum atau aturan, serta kurang menerapkan model pembelajaran dan keterampilan proses yang efektif untuk menemukan konsep dalam suatu pokok bahasan. Siswa belajar konsep melalui membaca buku atau mendengarkan penjelasan guru. Akibatnya, kepercayaan siswa terhadap sains atau pembelajaran IPA dibentuk melalui pemberitahuan orang lain, tidak melalui pengamatan yang dilakukan sendiri. Hal ini sejalan dengan pernyataan mengenai keterampilan proses sains di 
Sekolah Dasar Tarakan Timur yang diungkapkan oleh Annisa, dkk (2017) yang menjelaskan bahwa guru sangat sedikit mengetahui tentang keterampilan proses sains dalam pembelajaran dan pembuatan soal, serta guru dalam membuat soal hanya mengacu pada indikator yang belum banyak mengarah pada beberapa keterampilan proses sains.

Berdasarkan hasil observasi dan wawancara dengan guru kelas IV-A SDN 049 Tarakan pada Oktober 2017 menunjukkan bahwa dalam pembelajaran di kelas guru pernah mengembangkan perangkat pembelajaran namun guru memiliki kendala pada penyesuaian materi dengan alat pembelajaran yang ada di sekolah khususnya pada pembelajaran IPA materi sifat-sifat benda. Perangkat pembelajaran yang biasanya digunakan oleh guru mengacu pada standar isi yaitu hanya terdiri dari silabus dan Rencana Pelaksanaan Pembelajaran (RPP). Guru menyampaikan materi menggunakan metode ceramah, tanya jawab, dan percobaan pada materi tertentu. Guru belum menerapkan pendekatan atau model pembelajaran pada materi sifat-sifat benda, seperti integrasi cooperative script dan keterampilan proses sains. Siswa diketahui belum pernah menggunakan keterampilan proses sains ketika melakukan percobaan atau pengamatan mengenai sifat-sifat benda, hal ini menyebabkan siswa sulit untuk membedakan sifat-sifat benda. Siswa juga mengalami kesulitan dalam membuat kalimat yang menggunakan istilah-istilah dalam pembelajaran IPA karena siswa kurang memahami kata-kata atau kalimat yang ada. Sumber belajar seperti buku ajar yang ada masih kurang dalam penyediaannya dan kata-kata atau kalimatnya masih terlalu sulit untuk dipahami sehingga siswa kesulitan menangkap isi buku dan pembelajaran belum menimbulkan kerja sama serta partisipasi aktif antar siswa, seperti siswa masih sulit melakukan diskusi kelompok.

Menurut Suparni (2015: 11-12) pembelajaran IPA di Sekolah Dasar berfungsi untuk memberikan pengetahuan dan wawasan tentang lingkungan alam, serta mengembangkan keterampilan. Pembelajaran IPA lebih bersifat memberi pengetahuan, melalui pengamatan. Anak usia SD adalah anak yang sedang mengalami pertumbuhan baik pertumbuhan intelektual, emosional, maupun pertumbuhan. Pembelajaran IPA masih menggunakan metode ceramah dan kegiatan belajar lebih berpusat pada guru (teacher center). Aktivitas siswa hanya mendengarkan penyampaian dari guru dan mencatat hal-hal yang dianggap penting. Guru menjelaskan IPA hanya sebatas produk dan sedikit proses. Hal ini disebabkan karena banyak materi yang harus disampaikan dan diselesaikan berdasarkan kurikulum yang digunakan. Pembelajaran IPA tidak dapat terpenuhi hanya dengan bertumpu pada produk, tetapi bagian yang terpenting adalah proses untuk pembuktian atau mendapatkan suatu konsep dalam pembelajaran IPA.

Permasalahan di atas dapat teratasi dengan mengembangkan perangkat pembelajaran menggunakan integrasi model pembelajaran kooperatif salah satunya adalah cooperative script dan keterampilan proses sains dalam pembelajaran IPA. Model pembelajaran cooperative script dan keterampilan proses sains mempunyai tujuan yang sama yaitu membuat siswa agar dapat berpartisipasi aktif, siswa dapat bekerja sama dengan teman kelompoknya, dapat mengembangkan rasa percaya diri, tanggung jawab, serta kesetiakawanan dalam memecahkan suatu permasalahan. Oleh karena itu, guru lebih mudah mengarahkan siswa ke sasaran akhir dari pembelajaran yaitu terciptanya kemudahan belajar yang akan dicapai oleh siswa.

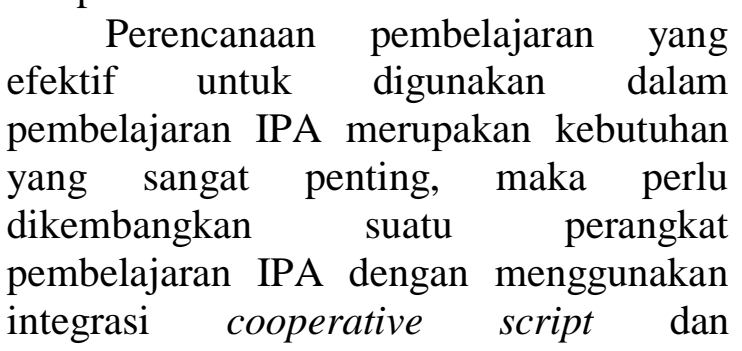


keterampilan proses sains untuk mendukung perbaikan pada pembelajaran IPA, baik dari segi pemahaman siswa, metode mengajar, dan sumber belajar. Oleh karena itu peneliti berinisiatif mengembangkan suatu perangkat pembelajaran yang dibuat berdasarkan tahapan-tahapan pada model pembelajaran cooperative script dan pendekatan keterampilan proses sains pada pembelajaran IPA di Sekolah Dasar.

Hal ini didukung juga dengan penelitian relevan yang dilakukan oleh Indriani, dkk (2015: 497-500) dengan judul pengembangan perangkat model cooperative script dalam pembelajaran IPA untuk meningkatkan pemahaman konsep IPA dan keterampilan berkomunikasi siswa di Sekolah Dasar. Hasil penelitian menunjukkan perangkat pembelajaran termasuk kategori valid, keterlaksanaan pembelajaran memperoleh kriteria baik dengan skala 3,97 dan kegiatan berpusat pada siswa (student center). Hasil tes pemahaman konsep yang diperoleh siswa dianalisis menggunakan $\mathrm{N}$-gain yang menunjukkan pemahaman konsep IPA siswa meningkat dengan perolehan rata-rata sebesar 0,65. Hasil keterampilan berkomunikasi diperoleh dengan skala 3,8 . Hasil penilaian sikap siswa menunjukkan hasil yang baik dengan skala 3,9. Berdasarkan hasil penilaian perangkat pembelajaran IPA model cooperative script menunjukkan bahwa perangkat pembelajaran tersebut layak dan memiliki pengaruh terhadap pemahaman konsep IPA dan keterampilan berkomunikasi siswa di Sekolah Dasar secara signifikan. Perbedaan penelitian peneliti dengan penelitian relevan yang dilakukan oleh Indriani, dkk adalah pada penggunaan model pembelajaran yang digunakan. Indriani, dkk menggunakan model pembelajaran cooperative script, sedangkan peneliti menggunakan integrasi cooperative script dan keterampilan proses sains.

Berdasarkan permasalahan di atas peneliti melakukan penelitian dengan judul
"Pengembangan Perangkat Pembelajaran IPA Integrasi Cooperative Script dan Keterampilan Proses Sains di Kelas IV-A SDN 049 Tarakan”.

\section{METODE PENELITIAN}

Penelitian yang dilakukan oleh peneliti menggunakan jenis penelitian pengembangan (Research and Development), yaitu mengacu pada model pengembangan perangkat Four-D Model (Model 4-D) yang terdiri dari tahap define, design, develop, disseminate. Penelitian hanya dibatasi sampai 3 tahapan karena mempertimbangkan waktu yang tersedia.. Perangkat pembelajaran yang dikembangkan berupa silabus, Rencana Pelaksanaan Pembelajaran (RPP), Buku Ajar Siswa (BAS), dan Lembar Kerja Siswa (LKS). Uji coba produk dilakukan sebagai dasar untuk mendeskripsikan kelayakan dari pengembangan perangkat pembelajaran IPA integrasi cooperative script dan keterampilan proses sains di kelas IV-A SDN 049 Tarakan, semester ganjil tahun ajaran 2017/2018. Subjek penelitian pada uji coba I melibatkan 6 orang siswa dan pada uji coba II melibatkan 33 orang siswa. Alur desain penelitian dan pengembangan perangkat pembelajaran IPA integrasi cooperative script dan keterampilan proses sains ditunjukkan pada gambar 1 . berikut.

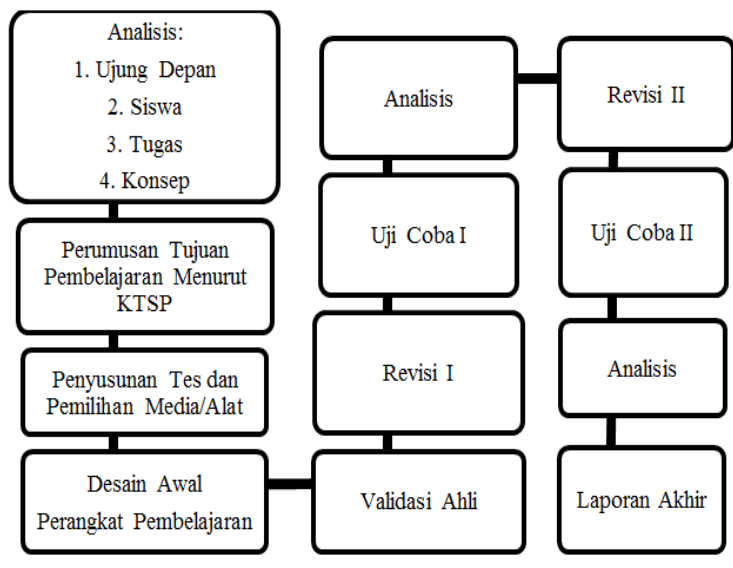

Gambar 1. Alur Desain 4-D Modifikasi Sampai Tahap 3-D (Thiagarajan dan Semmel dalam Aufika, 2015: 48) 


\section{Teknik Pengumpulan Data}

Teknik pengumpulan data pada penelitian ini, yaitu melalui wawancara, observasi, tes, kuesioner atau angket, dan dokumentasi mengenai pengembangan perangkat pembelajaran IPA integrasi cooperative script dan keterampilan proses sains di kelas IV-A SDN 049 Tarakan.

\section{Instrumen Pengumpulan Data}

Instrumen dalam penelitian ini terdiri dari: lembar wawancara guru, lembar validasi perangkat pembelajaran, lembar angket respon siswa, lembar observasi keterlaksanaan pembelajaran dan aktivitas siswa, serta lembar soal tes hasil belajar.

\section{Teknik Analisis Data}

Teknik analisis data dalam penelitian ini, sebagai berikut:

\section{a. Analisis kelayakan perangkat pembelajaran}

Teknik analisis kelayakan perangkat pembelajaran meliputi analisis validasi ahli materi/isi, konstruk, dan bahasa untuk silabus, Rencana Pelaksanaan (RPP), Buku Ajar Siswa (BAS), dan Lembar Kerja Siswa (LKS). Analisis data yang digunakan yaitu Pembelajaran analisis deskriptif kuantitatif, selanjutnya dijabarkan dengan menggunakan analisis deskriptif kualitatif untuk mendeskripsikan kualitas angka-angka tersebut. Lembar validasi perangkat pembelajaran yang digunakan pada penelitian ini menggunakan lima kriteria penskoran, sehingga menurut Apriyanti (2017:27) skor penilaian dapat dihitung menggunakan modifikasi rumus sebagai berikut:

$$
\text { skor penilaian }=\frac{\text { jumlah } \text { skor pada instrumen }}{\text { jumlah nilai } \text { skor tertinggi }} \times 5
$$

Hasil skor penilaian validasi perangkat pembelajaran disesuaikan dengan kriteria pada tabel 1. berikut.

Tabel 1. Modifikasi Skor Validasi Perangkat Pembelajaran

\begin{tabular}{cccl}
\hline No & Skor & Kriteria & \multicolumn{1}{c}{ Kesimpulan } \\
\hline 1. & $1,00 \leq \mathrm{SV} \leq 1,79$ & Tidak baik & $\begin{array}{l}\text { Tidak layak, belum dapat digunakan dan masih memerlukan } \\
\text { konsultasi }\end{array}$ \\
2. & $1,80 \leq \mathrm{SV} \leq 2,59$ & Kurang baik & Kurang layak, dapat digunakan dengan revisi lebih besar \\
3. & $2,60 \leq \mathrm{SV} \leq 3,39$ & Cukup baik & Cukup layak, dapat digunakan dengan revisi kecil \\
4. & $3,40 \leq \mathrm{SV} \leq 4,19$ & Baik & Layak, dapat digunakan tanpa revisi \\
5. & $4,20 \leq \mathrm{SV} \leq 5,00$ & Sangat baik & Sangat layak, dapat digunakan tanpa revisi \\
\hline
\end{tabular}

Keterangan: SV = Skor Validasi

Sumber: Kohar, dkk, 2014: 1292

\section{b. Analisis respon siswa}

Teknik analisis data hasil respon yang diberikan siswa dianalisis dengan menggunakan analisis deskriptif kuantitatif, selanjutnya hasil analisis tersebut dijabarkan dengan menggunakan analisis deskriptif kualitatif untuk memperoleh pernyataan yang menggambarkan kualitas angka-angka tersebut. Menurut Indiani (2015: 52) skor rata-rata penilaian respon siswa dapat dihitung dengan menggunakan rumus sebagai berikut:

Skor rata-rata $=$ Skor total
Hasil perhitungan skor rata-rata respon siswa disesuaikan dengan kriteria pada tabel 2. berikut.

Tabel 2. Modifikasi Skor Respon Siswa

\begin{tabular}{ccc}
\hline No. & Skor & Kriteria \\
\hline 1. & $1,00-1,79$ & Tidak baik \\
2. & $1,80-2,59$ & Kurang baik \\
3. & $2,60-3,39$ & Cukup baik \\
4. & $3,40-4,19$ & Baik \\
5. & $4,20-5,00$ & Sangat baik \\
\hline
\end{tabular}

Sumber: Sudjana dalam Dapa (2017: 81) 


\section{c. Analisis keterlaksanaan pembelajaran}

Teknik analisis data keterlaksanaan pembelajaran dianalisis secara deskriptif kuantitatif, selanjutnya hasil analisis tersebut dijabarkan dengan menggunakan analisis deskriptif kualitatif untuk mendeskripsikan pernyataan yang menggambarkan kualitas angka-angka tersebut. Aufika (2015: 62) menyatakan persentase keterlaksanaan pembelajaran dapat dihitung menggunakan rumus sebagai berikut:

$$
k=\frac{\text { skor tiap aspek }}{\text { skor maksimal tiap aspek }} \times 100 \%
$$

Hasil perhitungan persentase keterlaksanaan pembelajaran disesuaikan dengan kriteria pada tabel 3. berikut.

Tabel 3. Modifikasi Persentase Keterlaksanaan Pembelajaran

\begin{tabular}{ccc}
\hline No. & Persentase (\%) & Kriteria \\
\hline 1. & $\mathrm{k} \geq 90$ & Sangat baik \\
2. & $80 \leq \mathrm{k}<90$ & Baik \\
3. & $70 \leq \mathrm{k}<80$ & Cukup baik \\
4. & $60 \leq \mathrm{k}<90$ & Kurang baik \\
5. & $\mathrm{k}<60$ & Tidak baik \\
\hline
\end{tabular}

Keterangan: $\mathrm{k}=$ keterlaksanaan pembelajaran Sumber: Sudjana dalam Aufika (2015: 62)

\section{d. Analisis aktivitas siswa}

Teknik analisis data pengamatan aktivitas siswa menggunakan deskriptif kuantitatif dan kualitatif untuk memberikan deskripsi aktivitas siswa selama kegiatan pembelajaran. Menurut Purwanto (2010: 102) persentase aktivitas siswa dapat dihitung menggunakan rumus sebagai berikut:

$$
N P=\frac{R}{S M} \times 100
$$

Keterangan:

$\mathrm{NP}=$ Nilai persen yang dicari atau yang diharapkan

$\mathrm{R}=$ Nilai atau skor mentah yang diperoleh (skor aktual)

$\mathrm{SM}=$ Skor maksimum ideal dari nilai atau skor (skor ideal)

Hasil skor pengamatan aktivitas siswa disesuaikan dengan kriteria pada tabel 4 . Berikut.
Tabel 4. Modifikasi Skor Aktivitas Siswa

\begin{tabular}{ccc}
\hline No. & Persentase (\%) & Kriteria \\
\hline 1. & $86-100$ & Sangat baik \\
2. & $76-85$ & Baik \\
3. & $60-75$ & Cukup baik \\
4. & $55-59$ & Kurang baik \\
5. & $\leq 54$ & Tidak baik \\
\hline
\end{tabular}

Sumber: Purwanto (2010: 103)

\section{e. Analisis hasil belajar}

Nilai yang diperoleh siswa dari tes hasil belajar disesuaikan dengan Kriteria Ketuntasan Minimal (KKM) mata pelajaran IPA di SDN 049 Tarakan. Kriteria Ketuntasan Minimal (KKM) yang diharapkan dari siswa adalah memperoleh nilai 70. Jika nilai siswa kurang dari 70 maka siswa dinyatakan tidak tuntas. Sebaliknya apabila nilai siswa lebih dari atau sama dengan 70 maka siswa dinyatakan tuntas. Menurut Clara, dkk (2012: 5) langkah-langkah yang dilakukan untuk menganalisis hasil belajar adalah sebagai berikut:

1) Mengoreksi dan mengolah tiap lembaran jawaban siswa yang sesuai dengan kunci jawaban.

2) Menghitung skor dan menentukan ketuntasan belajar tiap siswa berdasarkan Kriteria Ketuntasan Minimal (KKM) yang telah ditetapkan oleh sekolah yaitu 70. Kriteria penskoran soal disesuaikan dengan kriteria pada tabel 5 . berikut.

Tabel 5. Modifikasi Kriteria Penskoran Soal

\begin{tabular}{ccc}
\hline Bentuk Soal & Skor & Keterangan \\
\hline \multirow{2}{*}{ Pilihan Ganda } & 1 & Jika jawaban benar \\
& 0 & Jika jawaban salah \\
\hline
\end{tabular}

Sumber: Suwarna (2013: 4)

3) Menurut Dapa (2017: 83) menghitung persentase ketuntasan belajar klasikal dapat menggunakan rumus sebagai berikut:

ketuntasan $(\mathrm{n})=\frac{\text { Jumlah semua siswa yang tuntas }}{\text { Jumlah seluruh siswa }} \times 100 \%$ 
Hasil persentase ketuntasan belajar disesuaikan dengan kriteria pada tabel 6 . berikut.

Tabel 6. Modifikasi Persentase Ketuntasan Belajar

\begin{tabular}{ccc}
\hline No. & Persentase (\%) & Kriteria \\
\hline 1. & $\mathrm{p}>80$ & Sangat baik \\
2. & $60<\mathrm{p} \leq 80$ & baik \\
3. & $40<\mathrm{p} \leq 60$ & Cukup baik \\
4. & $20<\mathrm{p} \leq 40$ & Kurang baik \\
5. & $\mathrm{p} \leq 20$ & Sangat Kurang baik \\
\hline Sumber: Widoyoko dalam Yuliana (2017: 64) \\
Keterangan: $\mathrm{p}=$ persentase ketuntasan \\
\multicolumn{3}{c}{ belajar }
\end{tabular}

HASIL

Kelayakan Perangkat Pembelajaran

Kelayakan perangkat pembelajaran diukur berdasarkan hasil validasi ahli isi, konstruk, dan bahasa.

1. Hasil Validasi Ahli Isi

Hasil analisis validasi ahli isi untuk silabus dan Rencana Pelaksanaan Pembelajaran (RPP), buku ajar siswa, dan lembar kerja siswa adalah sebagai berikut.

Tabel 7. Hasil Validasi Isi

\begin{tabular}{lcc}
\hline \multicolumn{1}{c}{ Perangkat } & Rata-rata & Kriteria \\
\hline Silabus dan RPP & 4,67 & Sangat baik \\
\hline Buku Ajar Siswa & 4,61 & Sangat baik \\
\hline LKS & 4,60 & Sangat baik \\
\hline
\end{tabular}

\section{Hasil Validasi Konstruk}

Hasil analisis validasi kontstruk untuk silabus dan Rencana Pelaksanaan Pembelajaran (RPP), buku ajar siswa, dan lembar kerja siswa adalah sebagai berikut.

Tabel 8. Hasil Validasi Konstruk

\begin{tabular}{lcl}
\multicolumn{1}{c}{ Perangkat } & Rata-rata & \multicolumn{1}{c}{ Kriteria } \\
\hline Silabus dan RPP & 4,20 & Sangat baik \\
\hline Buku Ajar Siswa & 4,00 & Baik \\
\hline LKS & 4,00 & Baik \\
\hline
\end{tabular}

\section{Hasil Validasi Bahasa}

Hasil analisis validasi bahasa untuk silabus dan Rencana Pelaksanaan Pembelajaran (RPP), buku ajar siswa, dan lembar kerja siswa adalah sebagai berikut.

Tabel 9. Hasil Validasi Bahasa

\begin{tabular}{lcl}
\multicolumn{1}{c}{ Perangkat } & Rata-rata & \multicolumn{1}{c}{ Kriteria } \\
\hline Silabus dan RPP & 4,14 & Baik \\
\hline Buku Ajar Siswa & 4,20 & Sangat baik \\
\hline LKS & 4,43 & Sangat baik \\
\hline
\end{tabular}

\section{Respon Siswa}

Lembar angket respon terhadap perangkat pembelajaran yang dikembangkan diberikan kepada siswa setelah mengikuti kegiatan pembelajaran. Hasil respon siswa dijabarkan pada Tabel 10 berikut.

Tabel 10. Hasil Respon Siswa

\begin{tabular}{|c|c|c|c|}
\hline No & Aspek & $\begin{array}{c}\text { Skor Rata- } \\
\text { Rata }\end{array}$ & Kriteria \\
\hline 1. & Materi atau isi pelajaran sangat menarik bagi saya & 4,83 & Sangat baik \\
\hline 2. & Format buku ajar dan LKS sangat menarik bagi saya & 4,33 & Sangat baik \\
\hline 3. & Suasana belajar dan cara mengajar guru sangat menarik bagi saya & 4,83 & Sangat baik \\
\hline 4. & Format buku ajar dan LKS merupakan sesuatu yang baru bagi saya & 4,2 & Sangat baik \\
\hline 5. & $\begin{array}{l}\text { Suasana belajar dan cara mengajar guru merupakan sesuatu yang baru bagi } \\
\text { saya }\end{array}$ & 5 & Sangat baik \\
\hline 6. & Saya mudah memahami bahasa dan materi isi buku & 4,83 & Sangat baik \\
\hline 7. & Saya mudah memahami LKS dan cara mengajar guru & 4,5 & Sangat baik \\
\hline 8. & $\begin{array}{l}\text { Saya dapat mengikuti dengan mudah komponen keterampilan proses sains } \\
\text { (mengamati, mengelompokkan, meramalkan, menafsirkan, dan } \\
\text { mengkomunikasikan) }\end{array}$ & 4,5 & Sangat baik \\
\hline 9. & Saya mudah memahami penjelasan guru & 5 & Sangat baik \\
\hline 10. & Saya mudah memahami bimbingan guru pada saat mengerjakan LKS & 4,67 & Sangat baik \\
\hline & $\begin{array}{l}\text { Saya berminat mengikuti pembelajaran seperti ini pada kegiatan belajar } \\
\text { berikutnya }\end{array}$ & 4,67 & Sangat baik \\
\hline & Saya mudah menjawab soal tes hasil belajar & 4,33 & Sangat baik \\
\hline & Rata-rata & 4,64 & Sangat baik \\
\hline
\end{tabular}




\section{Keterlaksanaan Pembelajaran}

Hasil analisis keterksanaan pembelajaran diukur berdasarkan langkah pembelajaran yaitu dari kegiatan pra pembelajaran, inti dan penutup. Hasil yang didapatkan sebagai berikut.

Tabel 11. Hasil Keterlaksanaan Pembelajaran

\begin{tabular}{lc}
\multicolumn{1}{c}{ Kegiatan } & \% Keterlaksanaan \\
\hline Pra Pembelajaran & $100 \%$ \\
\hline Inti & $96,40 \%$ \\
\hline Penutup & $90 \%$ \\
\hline \multicolumn{2}{c}{ Rata-rata } \\
\hline
\end{tabular}

\section{Aktivitas Siswa}

Hasil rata-rata aktivitas siswa secara keseluruhan yaitu 4,65 dengan persentase mencapai $93 \%$.

\section{Hasil Belajar}

Hasil belajar siswa dilihat dari ketuntasan siswa di dalam kelas, yaitu sebagai berikut.

Tabel 12. Hasil Belajar

\begin{tabular}{lc}
\hline \multicolumn{1}{c}{ Ketuntatasan } & $\boldsymbol{\%}$ \\
\hline Tuntas & $94 \%$ \\
\hline Tidak Tuntas & $6 \%$ \\
\hline
\end{tabular}

\section{PEMBAHASAN}

\section{Kelayakan Perangkat Pembelajaran}

Validasi ahli pada penelitian ini meliputi validasi ahli isi, konstruk dan bahasa. Purwanto (2008: 120) menjelaskan bahwa validasi isi merupakan pengujian validasi yang dilakukan atas isinya untuk menilai kelayakan komponen perangkat pembelajaran. Sedangkan validasi konstruk merupakan validasi yang dilakukan dengan menilai kelayakan komponen perangkat pembelajaran berdasarkan konstruksinya. Selanjutnya, Prasetya (2012: 109) menjelaskan bahwa validasi bahasa menjelaskan apakah kalimat pada komponen perangkat pembelajaran menggunakan bahasa yang sesuai kaidah bahasa Indonesia atau tidak.

Validasi ahli isi dilakukan oleh guru SDN 049 Tarakan yang ahli di bidangnya, sedangkan validasi ahli konstruk dilakukan oleh dosen Pendidikan Guru Sekolah Dasar, dan ahli bahasa dilakukan oleh dosen Pendidikan Bahasa dan Sastra Indonesia sesuai dengan kepakarannya masing-masing. Adapun penjabaran hasil validasi ahli isi, konstruk, dan bahasa adalah sebagai berikut.

\section{a. Validasi ahli isi/materi}

Hasil analisis validasi ahli isi untuk silabus dan Rencana Pelaksanaan Pembelajaran (RPP) dengan perolehan skor 4 menunjukkan bahwa silabus dan Rencana Pelaksanaan Pembelajaran (RPP) sesuai dengan integrasi cooperative script dan keterampilan proses sains yang terdiri dari kegiatan mengamati (observasi), mengelompokkan (klasifikasi), meramalkan (prediksi), menafsirkan (interpretasi) dan mengkomunikasikan serta langkah-langkah pembelajaran dirumuskan dengan jelas dan mudah dipahami, dan perolehan skor 5 menunjukkan bahwa standar kompetensi, kompetensi dasar dan indikator dirumuskan dengan jelas, tujuan pembelajaran dirumuskan dengan jelas, tujuan pembelajaran sesuai dengan indikator, perumusan tujuan sesuai dengan aspek Audience, Behaviour, Condition, Degree (ABCD).

Permendiknas Nomor 41 Tahun 2007 Tentang Standar Proses menjelaskan bahwa silabus dan Rencana Pelaksanaan Pembelajaran (RPP) disusun dengan memperhatikan keterkaitan antara standar kompetensi, kompetensi dasar, materi pembelajaran, kegiatan pembelajaran, indikator pencapaian kompetensi, evaluasi atau penilaian, dan media/alat/sumber belajar dalam satu keutuhan pengalaman belajar. Hasil validasi ahli isi untuk silabus dan Rencana Pelaksanaan Pembelajaran (RPP) memperoleh skor rata-rata sebesar 4,67 dan berada pada kriteria sangat baik.

Hasil analisis validasi ahli selanjutnya yaitu validasi ahli isi untuk Buku Ajar Siswa (BAS) dengan perolehan skor 4 menunjukkan bahwa contoh yang digunakan akurat, menggunakan contoh yang terdapat dalam kehidupan sehari-hari, 
menumbuhkan rasa ingin tahu, memberi tantangan pada siswa untuk lebih giat belajar dan sesuai dengan pembelajaran integrasi cooperative script dan keterampilan proses sains yang terdiri dari kegiatan mengamati (observasi), mengelompokkan (klasifikasi), meramalkan (prediksi), menafsirkan (interpretasi) dan mengkomunikasikan, perolehan skor 5 menunjukkan bahwa keluasan, kedalaman, kelengkapan materi yang sesuai dengan standar kompetensi dan kompetensi dasar, keakuratan fakta, konsep, gambar/diagram/ilustrasi dalam kehidupan sehari-hari, dan hasil validasi ahli isi untuk Buku Ajar Siswa (BAS) memperoleh skor rata-rata sebesar 4,61 dan berada pada kriteria sangat baik. Hal ini sejalan dengan pernyataan yang diungkapkan oleh Zuchdi dalam Akbar (2015: 34-35) yang menjelaskan bahwa untuk dapat menghasilkan buku ajar yang baik perlu memperhatikan akurasi dan memiliki kesesuaian (relevansi) antara keseluruhan komponen.

Validasi ahli isi yang terakhir yaitu validasi ahli isi untuk Lembar Kerja Siswa (LKS). Hasil analisis validasi ahli isi untuk Lembar Kerja Siswa (LKS) dengan perolehan skor 4 menunjukkan bahwa merupakan materi atau tugas yang esensial dan berperan untuk mendorong siswa dalam menemukan konsep atau prosedur dengan cara mereka sendiri, perolehan skor 5 menyatakan bahwa kebenaran isi atau materi, pengelompokkan dalam bagian-bagian yang logis, kesesuaian dengan pembelajaran integrasi cooperative script dan keterampilan proses sains yang terdiri dari kegiatan mengamati (observasi), mengelompokkan (klasifikasi), meramalkan (prediksi), menafsirkan (interpretasi) dan mengkomunikasikan. Hal ini didukung juga oleh pendapat dari Aufika (2015: 3233) yang menyatakan bahwa pemilihan materi pembelajaran dalam Lembar Kerja Siswa (LKS) siswa seharusnya berpedoman pada pemahaman bahwa materi pembelajaran tersebut menyediakan aktivitas-aktivitas yang berpusat pada siswa sebagai subjek dalam pembelajaran. Siswa dapat menemukan sendiri suatu konsep melalui serangkaian kegiatan yang mereka lakukan sehingga mereka tidak perlu menghafalkan konsep tersebut tetapi secara langsung terlibat dalam kegiatan menemukan konsep. Hasil validasi ahli isi untuk Lembar Kerja Siswa (LKS) memperoleh skor rata-rata sebesar 4,6 dan berada pada kriteria sangat baik.

Saran dan masukan yang diperoleh berdasarkan hasil validasi ahli isi yaitu memperhatikan kesesuaian langkahlangkah silabus dan Rencana Pelaksanaan Pembelajaran (RPP), isi materi sesuaikan dengan contoh yang ada pada lingkungan siswa, dan menambahkan benda yang akan digunakan siswa untuk praktek pada Lembar Kerja Siswa (LKS) sifat-sifat benda padat.

\section{b. Validasi ahli konstruk}

Penilaian validasi ahli konstruk untuk silabus dan Rencana Pelaksanaan Pembelajaran (RPP) dengan perolehan skor 4 menunjukkan bahwa terdapat satuan pendidikan, kelas, semester, mata pelajaran, alokasi waktu, menuliskan standar kompetensi, kompetensi dasar, indikator, tujuan pembelajaran sesuai dengan indikator, perumusan tujuan sesuai dengan aspek Audience, Behaviour, Condition, Degree (ABCD), menampilkan kegiatan pendahuluan, inti, dan penutup dengan jelas, kegiatan pembelajaran sesuai dengan sistematika atau keruntutan materi, alokasi waktu sesuai dengan kegiatan pendahuluan, inti, dan penutup dinyatakan dengan jelas, perolehan skor 5 menyatakan bahwa penggunaan Buku Ajar Siswa (BAS) dan Lembar Kerja Siswa (LKS) diskenariokan dalam Rencana Pelaksanaan Pembelajaran (RPP), bentuk, teknik dan instrumen penilaian sesuai dengan indikator pencapaian kompetensi.

Hal tersebut juga diungkapkan oleh Daryanto dan Dwicahyono (2014: 10) yang menjelaskan bahwa silabus dan Rencana Pelaksanaan Pembelajaran (RPP) memuat sekurang-kurangnya komponen- 
komponen, yaitu identitas mata pelajaran, standar kompetensi, kompetensi dasar, materi pembelajaran, kegiatan pembelajaran, indikator pencapaian kompetensi, penilaian, alokasi waktu, dan sumber belajar. Hasil validasi ahli konstruk untuk silabus dan Rencana Pelaksanaan Pembelajaran (RPP) memperoleh skor rata-rata sebesar 4,2 dan berada pada kriteria sangat baik.

Hasil analisis validasi ahli selanjutnya yaitu validasi ahli konstruk untuk Buku Ajar Siswa (BAS) secara keseluruhan memperoleh skor 4 yang menunjukkan bahwa kelogisan penyajian, keterurutan konsep, hubungan antar fakta, antar konsep dan antar teori, ilustrasi sesuai dengan materi, penyajian tabel/gambar/grafik disertai dengan rujukan, memberikan identitas pada tabel/gambar/lampiran, memiliki pengantar, ringkasan, glosarium/kamus IPA, daftar pustaka, keterlibatan siswa/interaktivitas (stimulus dan respon), kesesuaian penggunaan font (jenis dan ukuran), lay out dan tata letak uraian serta desain tampilan. Istiqomah (2013: 25) menyatakan bahwa buku yang baik disajikan secara menarik dilengkapi dengan gambar dan keteranganketerangannya serta menggambarkan sesuatu yang sesuai dengan ide penulisannya. Hasil validasi ahli konstruk untuk Buku Ajar Siswa (BAS) memperoleh skor rata-rata sebesar 4 dan berada pada kriteria baik.

Validasi ahli konstruk yang terakhir yaitu validasi ahli konstruk untuk Lembar Kerja Siswa (LKS). Hasil analisis validasi ahli konstruk untuk Lembar Kerja Siswa (LKS) secara keseluruhan juga memperoleh skor 4 yang menunjukkan bahwa kegiatan pembelajaran sesuai dengan tujuan (indikator pencapaian kompetensi), prosedur urutan kerja, bermanfaat terhadap pembelajaran, memiliki keterbacaan atau kejelasan bahasa dan berperan mengaktifkan belajar siswa.
Madjid dalam Pranata (2014: 6) menyatakan bahwa Lembar Kerja Siswa (LKS) biasanya berupa petunjuk, langkahlangkah untuk menyelesaikan suatu tugas. Tugas yang diperintahkan harus tergambar jelas tujuan apa yang akan dicapai pada lembar kerja tersebut. Hasil validasi ahli konstruk untuk Lembar Kerja Siswa (LKS) memperoleh skor rata-rata sebesar 4 dan berada pada kriteria baik. Saran dan masukan yang diperoleh berdasarkan hasil validasi ahli konstruk yaitu masih terdapat sedikit kekurangan karena kesalahan pengetikan atau minim contoh.

\section{c. Validasi ahli bahasa}

Penilaian validasi ahli bahasa untuk silabus dan Rencana Pelaksanaan Pembelajaran (RPP) dengan perolehan skor 3 menunjukkan ketepatan tata bahasa, perolehan skor 4 menyatakan bahwa bahasa yang digunakan sesuai dengan kaidah bahasa Indonesia yang baku, ketepatan struktur kalimat, tulisan mengikuti aturan ejaan yang disempurnakan, ketepatan ejaan, perolehan skor 5 menyatakan bahwa bahasa yang digunakan bersifat komunikatif dan mudah dipahami. Berdasarkan Permendiknas Nomor 41 Tahun 2007 tentang Standar Proses menjelaskan bahwa silabus dan Rencana Pelaksanaan Pembelajaran (RPP) dirancang untuk mengembangkan pemahaman beragam bacaan dan dalam berbagai bentuk tulisan. Hasil validasi bahasa untuk silabus dan Rencana Pelaksanaan Pembelajaran (RPP) memperoleh skor rata-rata sebesar 4,14 dan berada pada kriteria baik.

Hasil analisis validasi ahli selanjutnya yaitu validasi ahli bahasa untuk Buku Ajar Siswa (BAS) dengan perolehan skor 3 menunjukkan bahwa ketertautan antar kalimat, perolehan skor 4 menyatakan bahwa sesuai dengan tahap perkembangan berpikir siswa, keterpahaman siswa terhadap pesan yang disampaikan, ilustrasi sesuai dengan substansi pesan, ketepatan struktur kalimat, ketepatan tata bahasa, ketepatan ejaan, perolehan skor 5 menyatakan bahwa 
sesuai dengan tahap perkembangan sosialemosional siswa, kebakuan istilah, keutuhan makna dalam setiap alinea. Hal yang sama juga diungkapkan oleh Akbar (2015: 36) yang menyatakan bahwa buku ajar yang disusun seharusnya menggunakan kaidah bahasa yang benar yaitu penggunaan ejaan, istilah, dan struktur kalimat yang tepat. Hasil validasi ahli bahasa untuk Buku Ajar Siswa (BAS) memperoleh skor rata-rata sebesar 4,2 dan berada pada kriteria sangat baik.

Validasi ahli bahasa yang terakhir yaitu validasi ahli bahasa untuk Lembar Kerja Siswa (LKS). Hasil analisis validasi ahli bahasa untuk Lembar Kerja Siswa (LKS) dengan perolehan skor 4 menunjukkan bahwa bahasa yang digunakan sesuai dengan kaidah bahasa Indonesia yang baku, ketepatan struktur kalimat, bahasa yang digunakan bersifat komunikatif, ketepatan tata bahasa, perolehan skor 5 menyatakan bahwa bahasa mudah dipahami, tulisan mengikuti aturan ejaan yang disempurnakan, ketepatan ejaan. Pranata (2014: 12) menjelaskan bahwa Lembar Kerja Siswa (LKS) yang baik harus memenuhi persyaratan yang meliputi penggunaan bahasa, susunan kalimat, kosakata, dan dapat dipahami oleh siswa. Hasil validasi ahli bahasa untuk Lembar Kerja Siswa (LKS) memperoleh skor rata-rata sebesar 4,43 dan berada pada kriteria sangat baik. Saran dan masukan yang diperoleh berdasarkan hasil uji validasi ahli bahasa yaitu lebih konsisten terhadap penggunaan kata dan struktur kalimat, mencermati konsistensi antar subbab dengan uraian dari subbab perangkat pembelajaran, dan revisi sesuai dengan kemampuan berdasarkan saran dari validator.

Penilaian validasi perangkat pembelajaran secara keseluruhan berdasarkan uji validasi ahli isi, konstruk dan bahasa untuk silabus dan Rencana Pelaksanaan Pembelajaran (RPP) secara keseluruhan diperoleh skor rata-rata sebesar 4,33 dengan kriteria sangat baik. Penilaian uji validasi ahli isi, konstruk dan bahasa untuk Buku Ajar Siswa (BAS) diperoleh skor rata-rata sebesar 4,27 dengan kriteria sangat baik. Penilaian validasi ahli isi, konstruk dan bahasa untuk Lembar Kerja Siswa (LKS) diperoleh skor rata-rata sebesar 4,34 dengan kriteria sangat baik. Berdasarkan hasil analisis tersebut dapat disimpulkan bahwa perangkat pembelajaran IPA integrasi cooperative script dan keterampilan proses sains di kelas IV-A SDN 049 Tarakan ditinjau dari hasil uji validasi isi, konstruk, dan bahasa secara keseluruhan menunjukkan skor rata-rata sebesar 4,31 dengan kriteria sangat baik sehingga dapat disimpulkan bahwa perangkat pembelajaran yang telah dikembangkan sangat layak. Revisi atau perbaikan dilakukan setelah uji validasi perangkat pembelajaran oleh ahli.

\section{Respon Siswa}

Lembar angket respon terhadap perangkat pembelajaran yang dikembangkan diberikan kepada siswa setelah mengikuti kegiatan pembelajaran untuk diisi serta siswa diminta untuk memberikan saran dan komentar terhadap perangkat pembelajaran tersebut. Hasil respon siswa telah dijabarkan pada Tabel 10.

Angket respon siswa memperoleh skor rata-rata keseluruhan sebesar 4,64 dengan kriteria sangat baik. Respon siswa dengan skor rata-rata sebesar 4,2 menunjukkan bahwa format buku ajar dan Lembar Kerja Siswa (LKS) merupakan sesuatu yang baru bagi siswa, skor ratarata sebesar 4,33 menyatakan bahwa format buku ajar dan Lembar Kerja Siswa (LKS) sangat menarik bagi siswa serta siswa mudah menjawab soal tes hasil belajar, skor rata-rata sebesar 4,5 menyatakan bahwa siswa mudah memahami Lembar Kerja Siswa (LKS) dan cara mengajar guru serta siswa dapat mengikuti dengan mudah komponen keterampilan proses sains yang terdiri dari kegiatan mengamati (observasi), mengelompokkan (klasifikasi), meramalkan (prediksi), menafsirkan (interpretasi) 
dan mengkomunikasikan, skor rata-rata sebesar 4,67 menyatakan bahwa siswa mudah memahami bimbingan guru pada saat mengerjakan Lembar Kerja Siswa (LKS) dan siswa berminat mengikuti pembelajaran seperti ini pada kegiatan belajar berikutnya, skor rata-rata sebesar 4,83 menyatakan bahwa materi atau isi pelajaran sangat menarik bagi siswa dan suasana belajar serta cara mengajar guru sangat menarik bagi siswa, selanjutnya siswa mudah memahami bahasa dan materi isi buku, skor rata-rata sebesar 5 menyatakan bahwa suasana belajar dan cara mengajar guru merupakan sesuatu yang baru serta siswa mudah memahami penjelasan guru.

Hal ini juga diungkapkan oleh Andini (2015: 864) yang menyatakan bahwa ketertarikan siswa dalam komponen perangkat pembelajaran yang dikembangkan membuat siswa lebih mudah untuk memahami perangkat pembelajaran yang dikembangkan. Saran dan komentar yang diberikan siswa, yaitu secara keseluruhan siswa merasa senang ketika mengikuti kegiatan pembelajaran. Siswa L merasa sangat senang dengan buku ajar IPA karena lebih mudah dimengerti dan dipahami serta penjelasan guru lebih singkat dan mudah dimengerti, siswa $\mathrm{R}$ merasa sangat senang mengikuti pembelajaran, siswa YP senang mempelajari dan melakukan kegiatan percobaan yang telah diajarkan oleh guru, siswa J sangat senang belajar dan mudah sekali memahami pelajaran dari guru serta format buku dan Lembar Kerja Siswa (LKS) mudah dipahami, selanjutnya siswa berharap dapat mengikuti kegiatan pembelajaran seperti ini lagi, siswa $Y$ senang sekali belajar mengenai materi sifat-sifat benda dan siswa menyukai pembelajaran bersama guru dan temannya serta siswa menyukai pembelajaran IPA, saran dan komentar yang terakhir yaitu dari siswa $\mathrm{S}$ yang merasa senang sekali mempelajari materi sifat-sifat benda dan menyukai pembelajaran IPA serta senang dalam mengerjakan soal tes hasil belajar yang diberikan oleh guru. Saran dan komentar yang diberikan digunakan sebagai acuan dalam melaksanakan uji coba pada tahap selanjutnya.

\section{Keterlaksanaan Pembelajaran}

Penilaian

keterlaksanaan pembelajaran dilakukan oleh dua orang observer menggunakan lembar observasi keterlaksanaan pembelajaran yang telah disusun. Hasil skor rata-rata keseluruhan keterlaksanaan pembelajaran adalah sebesar 4,8 dengan persentase 95,47\%. Sudjana dalam Aufika (2015: 62) menyatakan bahwa keterlaksanaan pembelajaran dikatakan sangat baik jika memiliki persentase $\mathrm{k} \geq 90 \%$. Hasil skor rata-rata keseluruhan keterlaksanaan pembelajaran menunjukkan bahwa perolehan tersebut termasuk dalam kriteria sangat baik.

Aspek penilaian prapembelajaran memperoleh skor rata-rata 5 dengan persentase $100 \%$ dan berada pada kriteria sangat baik. Hal ini dikarenakan guru mempersiapkan siswa untuk belajar secara fisik dan psikis sebelum mengikuti kegiatan pembelajaran dan guru melakukan kegiatan apersepsi dan motivasi dengan mengajak siswa bernyanyi sebuah lagu mengenai materi sifat-sifat benda dengan irama "Balonku" dan bertanya jawab serta guru juga menyampaikan tujuan pembelajaran yang akan dicapai oleh siswa.

Aspek penilaian selanjutnya yaitu kegiatan inti memperoleh skor rata-rata 4,82 dengan persentase $96,4 \%$ dan berada pada kriteria sangat baik. Hal ini menunjukkan bahwa guru menguasai materi pembelajaran, mengaitkan materi dengan pengetahuan lain yang relevan, menyampaikan materi dengan jelas sesuai dengan hierarki belajar dan karakteristik siswa, melaksanakan pembelajaran sesuai dengan kompetensi (tujuan) yang akan dicapai, melaksanakan pembelajaran secara runtut, menguasai kelas, melaksanakan pembelajaran yang sesuai dengan integrasi cooperative script dan keterampilan proses sains, melaksanakan 
pembelajaran yang menimbulkan partisipasi aktif siswa dalam mengajukan pertanyaan dan mengemukakan pendapat serta melaksanakan pembelajaran sesuai dengan alokasi waktu yang direncanakan.

Penerapan pendekatan keterampilan proses sains pada kegiatan inti menunjukkan bahwa terdapat kegiatan memfasilitasi dan menyajikan kegiatan bagi siswa untuk mengamati (observasi), mengelompokkan (klasifikasi), meramalkan (prediksi), menafsirkan (interpretasi), mengkomunikasikan pengetahuan dan keterampilan yang diperoleh siswa. Pemanfaatan sumber belajar atau media pembelajaran pada kegiatan pembelajaran menunjukkan bahwa media digunakan secara efektif dan efisien, menghasilkan pesan yang menarik, dan guru melibatkan siswa dalam pemanfaatan media. Pembelajaran yang memicu dan memelihara keterlibatan siswa pada kegiatan inti menunjukkan bahwa pembelajaran menumbuhkan partisipasi aktif siswa, guru menunjukkan sikap terbuka terhadap respon siswa dan menumbuhkan keceriaan serta antusiasme siswa dalam belajar. Penilaian proses dan hasil belajar pada kegiatan pembelajaran menunjukkan bahwa guru memantau kemajuan belajar siswa selama proses pembelajaran dan melakukan penilaian di awal dan akhir sesuai dengan kompetensi (tujuan). Penggunaan bahasa selama pembelajaran menunjukkan bahwa guru menggunakan bahasa lisan dan tulis secara jelas, baik, dan benar serta menyampaikan pesan dengan gaya yang sesuai. Hal ini sesuai dengan pendapat yang diungkapkan oleh Andini (2015: 864) yang menjelaskan bahwa pelaksanaan pembelajaran terlaksana dengan baik karena proses pembelajaran yang dilakukan mengikuti tahap sesuai yang tertulis pada masingmasing Rencana Pelaksanaan Pembelajaran (RPP) sesuai dengan pendekatan atau model pembelajaran yang digunakan.

Aspek penilaian kegiatan penutup memperoleh skor rata-rata 4,5 dengan persentase $90 \%$ dan berada pada kriteria sangat baik. Hal ini menunjukkan bahwa guru melakukan kegiatan refleksi terhadap hasil pembelajaran yang telah diikuti oleh siswa dengan melibatkan siswa secara langsung yaitu siswa mengukapkan materi apa saja yang telah dipelajari dan perasaannya setelah mengikuti pembelajaran serta guru melaksanakan tindak lanjut pada siswa berupa kesimpulan hasil pembelajaran.

Pembelajaran

menggunakan perangkat pembelajaran IPA integrasi cooperative script dan keterampilan proses sains memiliki kelebihan yaitu dengan adanya Buku Ajar Siswa (BAS) dengan materi sifat-sifat benda yang disusun menggunakan integrasi cooperative script dan keterampilan proses sains yang digunakan oleh siswa maupun guru dalam kegiatan pembelajaran serta Lembar Kerja Siswa (LKS) yang terdiri dari 3 lembar kerja (sifat-sifat benda padat, cair, dan gas) yang juga disusun menggunakan integrasi cooperative script dan keterampilan proses sains yang digunakan siswa dalam melakukan kegiatan percobaaan baik di dalam maupun di luar kelas untuk menemukan konsep yang dipelajari serta dimana peneliti juga berperan sebagai guru dalam penerapan perangkat pembelajaran IPA integrasi cooperative script dan keterampilan proses sains. Namun karena keterbatasan biaya, pemanfaatan sumber belajar berupa Buku Ajar Siswa (BAS) dalam penelitian ini peneliti hanya menggunakan sebanyak 12 buku yaitu siswa dibagi terlebih dahulu menjadi beberapa kelompok kecil dengan beranggotakan 2-3 orang siswa yang setiap kelompoknya mendapatkan 1 buah Buku Ajar Siswa (BAS).

\section{Aktivitas Siswa}

Penilaian aktivitas siswa dilakukan menggunakan lembar observasi aktivitas siswa yang diamati oleh dua orang observer. Hasil skor rata-rata keseluruhan aktivitas siswa adalah sebesar 4,65 dengan persentase 93\%. Purwanto (2010: 103) menjelaskan bahwa aktivitas siswa 
termasuk dalam kriteria sangat baik jika memiliki persentase $86 \%-100 \%$. Hasil skor rata-rata keseluruhan aktivitas siswa menunjukkan bahwa perolehan tersebut termasuk dalam kriteria sangat baik. Hal ini dikarenakan siswa mempersiapkan buku catatan dan buku pelajaran untuk mengikuti pembelajaran ketika guru mempersiapkan siswa untuk mengikuti proses pembelajaran baik secara mental dan fisik memperoleh skor rata-rata 5 dengan persentase $100 \%$, siswa menjawab pertanyaan dari guru dengan cara menjelaskan maksud atau jawaban dari pertanyaan secara bergantian ketika guru melakukan kegiatan tanya jawab memperoleh skor rata-rata 5 dengan persentase $100 \%$, siswa menyimak guru dan memperhatikan dengan sungguhsungguh serta mencatatnya ketika guru menyampaikan tujuan pembelajaran yang akan dicapai dan materi pembelajaran melalui Power Point (PPT) dan Buku Ajar Siswa (BAS) memperoleh skor rata-rata 5 dengan persentase $100 \%$, kemudian siswa saling berbagi dan bekerja sama dengan pasangan atau kelompoknya ketika guru meminta siswa untuk berdiskusi dan membahas hal-hal yang akan dilakukan sebelum siswa melakukan praktek sesuai dengan kelompoknya memperoleh skor rata-rata 5 dengan persentase $100 \%$.

Aspek penilaian aktivitas siswa selanjutnya menunjukkan bahwa siswa mengikuti dengan seksama segala sesuatu yang sedang disampaikan oleh guru ketika guru menyampaikan penjelasan mengenai materi maupun ketika mengarahkan siswa untuk melakukan kegiatan dalam pembelajaran memperoleh skor rata-rata 4,5 dengan persentase $90 \%$, ketika melakukan kegiatan percobaan siswa tampak antusias dan percaya diri memperoleh skor rata-rata 4,5 dengan persentase $90 \%$, siswa berani dalam mengemukakan pendapatnya maupun memberikan komentar kepada kelompok lain setelah melakukan percobaan dan membacakan hasil ringkasan ketika guru bertanya dalam proses pembelajaran maupun pada kegiatan refleksi, dan siswa menyimak temannya ketika siswa lain melakukan kegiatan percobaan maupun mengungkapkan pendapat atau memberikan komentar kepada temannya memperoleh skor rata-rata 4 dengan persentase $80 \%$. Hal ini sejalan dengan pernyataan yang diungkapkan oleh Muslim dan Supriatna (2016: 6) yang menjelaskan bahwa aktivitas siswa selama proses belajar mengajar merupakan salah satu indikator adanya keinginan siswa untuk belajar. Dengan demikian, perlu diterapkan suatu pembelajaran baru yang lebih menggali aktivitas belajar siswa.

\section{Hasil Belajar}

Pada kegiatan akhir pembelajaran siswa diminta untuk mengerjakan soal tes hasil belajar. Hasil belajar siswa secara keseluruhan menunjukkan persentase ketuntasan siswa mencapai 94\% (sangat baik). Widoyoko dalam Yuliana (2017: 64) menyatakan bahwa hasil belajar termasuk dalam kriteria sangat baik jika persentase ketuntasan belajar siswa mencapai $\mathrm{p}>$ $80 \%$. Pembelajaran dengan menggunakan pendekatan keterampilan proses sains dapat meningkatkan hasil belajara siswa, hal ini senada dengan pernyataan Alamsyah, dkk (2018) yang menyatakan bahwa penggunaan keterampilan proses sains dapat meningkatkah hasil belajar siswa kelas V-B SDN 045 Tarakan.

\section{KESIMPULAN}

Berdasarkan proses penelitian dan pengembangan yang dilakukan, maka dapat disimpulkan sebagai berikut:

1. Perangkat pembelajaran IPA integrasi cooperative script dan keterampilan proses sains telah dikembangkan dan sangat layak berdasarkan hasil uji validasi isi, kontruk, dan bahasa. Secara keseluruhan menunjukkan skor rata-rata sebesar 4,31 dengan kriteria sangat baik sehingga dapat disimpulkan bahwa perangkat pembelajaran yang telah dikembangkan sangat layak, yaitu: 
a. Silabus dan Rencana Pelaksanaan Pembelajaran (RPP) secara keseluruhan memperoleh skor rata-rata sebesar 4,33 dengan kriteria sangat baik.

b. Buku Ajar Siswa (BAS) memperoleh skor rata-rata sebesar 4,27 dengan kriteria sangat baik.

c. Lembar Kerja Siswa (LKS) memperoleh skor rata-rata sebesar 4,34 dengan kriteria sangat baik.

2. Respon siswa setelah mengikuti kegiatan pembelajaran menggunakan perangkat pembelajaran IPA integrasi cooperative script dan keterampilan proses sains menunjukkan hasil perolehan skor rata-rata keseluruhan sebesar 4,64 dengan kriteria sangat baik.

\section{DAFTAR PUSTAKA}

Akbar, Sa'dun. 2015. Instrumen Perangkat Pembelajaran. Bandung: PT Remaja Rosdakarya.

Andini. 2015. Pengembangan Perangkat Pembelajaran Biologi Berbahasa Inggris dengan Pendekatan Keterampilan Proses pada Materi Kingdom Jamur. Pendidikan Sains Pascasarjana Universitas Negeri Surabaya, 5 (1): 859-866.

Alamsyah, S., Annisa, M., \& Kusnadi, D. (2018). Penerapan Pendekatan Keterampilan Proses Sains Untuk Meningkatkan Hasil Belajar Ipa Siswa Kelas Vb SDN 045 Tarakan. LENSA (Lentera Sains): Jurnal Pendidikan IPA, 8(1).

Annisa, M., Yulinda, R., \& Mas'an Al Wahid, S. (2017). The Analysis of Science Process Skills on Natural Science Questions at Elementary Schools in Tarakan. Advances in Social Science, Education and Humanities Research 5th South East Asia Development Research (SEADR) International Conference, Vol 100: p. 298-301.

Apriyanti, Yeni. 2017. Pengembangan Perangkat Pembelajaran Classroom
Pada Materi Getaran Harmonis. Bandar Lampung: Universitas Lampung.

Aufika, Hasnan. 2015. Pengembangan Perangkat Pembelajaran Matematika Berbasis Problem Based Learning (PBL) Pada Materi Perbandingan dan Skala Untuk Meningkatkan Kemampuan Pemecahan Masalah Siswa SMP Kelas VII. Yogyakarta: Universitas Negeri Yogyakarta.

Clara, dkk. 2012. Miskonsepsi Siswa Kelas Rangkap SDN 47 Sekadau Pada Materi Sifat dan Perubahan Wujud Benda. Pontianak: FKIP UNTAN Pontianak.

Dapa, Philomena Theresia Nggowa. 2017. Pengembangan Perangkat Pembelajaran Matematika Menggunakan Paradigma Pedagogi Reflektif dan Model Pembelajaran Problem Solving Pada Materi Garis Singgung Lingkaran di Kelas VIII H SMP Negeri 1 Yogyakarta. Yogyakarta: Universitas Sanata Dharma.

Daryanto dan Dwicahyono. 2014. Pengembangan Perangkat Pembelajaran (Silabus, RPP, PHB, Bahan Ajar). Yogyakarta: Gava Media.

Indiani, Venti. 2015. Pengembangan Perangkat Pembelajaran Berbasis Contextual Teaching And Learning (CTL) pada Materi Barisan dan Deret Untuk Siswa SMA Siswa Kelas $X$. Yogyakarta: Universitas Negeri Yogyakarta.

Indriani. 2015. Pengembangan Perangkat Model Cooperative Script Dalam Pembelajaran IPA Untuk Meningkatkan Pemahaman Konsep IPA dan Keterampilan Berkomunikasi Siswa di Sekolah Dasar. Pendidikan Sains Pascasarjana Universitas Negeri Surabaya, 4 (2): 495-502.

Istiqomah, Nuriyah. 2013. Pengembangan Bahan Ajar Ilmu Pengetahuan Alam 
Materi Perubahan Wujud Benda dan Sifatnya dengan Metode Eksperimen Untuk Siswa Kelas IV SDN Sumbersari 2 Malang. Malang: Universitas Islam Negeri Maulana Malik Ibrahim.

Kohar, dkk. 2017. Pengembangan Perangkat Pembelajaran Berbasis Inkuiri Terbimbing Menggunakan Simulasi PhEt untuk mereduksi Miskonsepsi Siswa. Pendidikan Sains Pascasarjana Universitas Negeri Surabaya, 6 (2): 1289-1301.

Muslim dan Supriatna. 2016. Pengembangan Perangkat Pembelajaran PKn Model Cooperative Tipe TGT Berbasis ATONG Bagi Siswa Sekolah Dasar. Jurnal Pendidikan Sekolah Dasar, 2 (2): 1-14.

Mustofa dan Asf. 2013. Supervisi Pendidikan: Terobosan Baru dalam Kinerja Peningkatan Kerja Pengawas Sekolah dan Guru. Jogjakarta: Ar-Ruzz Media.

Prasetya, Tri Indra. 2012. Meningkatkan Keterampilan Menyusun Instrumen Hasil Belajar Berbasis Modul Interaktif Bagi Guru-Guru IPA SMPN Kota Magelang. Journal of Educational Research and Evaluation, 1 (2): 106-112.

Purwanto. 2008. Evaluasi Hasil Belajar. Yogyakarta: Pustaka Pelajar.

Purwanto, M. Ngalim. 2010. PrinsipPrinsip dan Teknik Evaluasi Pengajaran. Bandung: PT Remaja Rosdakarya.

Permendiknas. 2007. Standar Proses. Jakarta: Badan Standar Nasional Pendidikan (BSNP).

Pranata. 2014. LKS. Lampung: Universitas Lampung.

Sulistyorini, dkk. 2016. Pengembangan Perangkat Pembelajaran IPA Model Guided Inquiry Untuk Melatihkan Keterampilan Proses Sains dan Meningkatkan Hasil Belajar Siswa SMP. Pendidikan Sains Pascasarjana
Universitas Negeri Surabaya, 6 (1): 1167-1174.

Susanto, Ahmad. 2013. Teori Belajar \& Pembelajaran di Sekolah Dasar. Jakarta: Kencana Prenada Media Group.

Suwarna. 2013. Analisis Miskonsepsi Siswa SMA Kelas X pada Mata Pelajaran Fisika Melalui CRI (Certainty Of Response Index) Termodifikasi. Jakarta: FITK UIN Syarif Hidayatullah Jakarta.

Yuliana, Rina. 2017. Pengembangan Perangkat Pembelajaran Dengan Pendekatan PMRI pada Materi Bangun Ruang Sisi Lengkung Untuk SMP Kelas IX. Jurnal Pendidikan Matematika, 6 (1): 60-67. 